Earth Common Journal Special Issue

$e^{3}=$ earth education economics

1st PRME Canada Regional Meeting held on June 12, 2013

MacEwan University, School of Business

Volume 3, Number 2, September 2013

\title{
Ecological education: Proposal of implementation programs in Romania
}

\author{
Mia Isabela Deleanu* \\ MacEwan University, Canada
}

\begin{abstract}
A Case Study
The following is a case study of the author's country of origin, Romania, and its journey back to sustainable living. Her article describes, outlines, and explains how Romania has undergone change with respect to its approach to sustainable living. She provides the political and economic background that underpins the struggles that Romania bas undertaken to return to its sustainable practices and lifestyle. Ecological education offers a solution.
\end{abstract}

\section{Introduction}

On the $22^{\text {nd }}$ of December, 1989, Romania freed itself from the Nicolae Ceausescu communist regime, and entered into a new era of freedom of information, democracy, and the right of propriety. Romanians have the power to change their faith, but also the power to destroy it. The revolution had brought a new democratic regime, and an inexperienced civil society, that did not know to appreciate the natural resources and the economically advantageous perspective it had inherited. Instead of keeping up with the new democratic situation, destruction became the new rule of order. Hiding behind the 
curtain of the new democratic regime, many opportunists took advantage and started a systematic process of changing the environmental image of a country that was known before as having pristine waters, wonderful forests, and wild panorama. Deforestation was one of those destructive processes that changed the composition of the soil, the water and the natural animal habitats (Educatia Ecologica, 2010-2013).

Within the last twenty years, the cutting down of trees has become a very big issue in Romania. People believed that it was okay to cut down a tree, and that no one was going to miss it; and for a while this "nobody cares" practice was working, but soon enough others in the circle got cut, and the first signs that the trees were important started to show. With significant sections of the forest gone, there was no natural barrier to keep the water away from Romanian villages when rain hit the ground. The deforestation, as a result of the unregulated practice, had as an end result the destabilization of the ecological system (Appendix I provides an excellent glimpse of the change in European forests in the past years) (Energy, transport and environment indicators - Eurostat -Europa, 2012).

Consequently, some villages have started to slip away from the old foundations they were initially built on. No matter how many warnings the population received from the forest authorities, the cutting did not stop until recently. People had misunderstood the right of possession, a right that came without the support of specific education and without the clear understanding of what civic responsibilities mean in relation to forest ecology. The people, who had official documents to prove that that particular forest belonged to their ancestors, and that the communist regime took that property away, got that property back from the government. As a result, without thought as to the longterm effects of their actions, the people who entered into possession of a forest started to cut the trees for immediate short-term revenue.

If we want to have a sustainable economy we have to preserve nature. Everything on planet Earth lives in a fragile equilibrium; once you start to destroy one element, the other dependent elements fall down. With no forests, animals are forced to live in a confined space, scarcity in food and shelter coerces them to migrate to spaces populated with humans, and fear and destruction open a new gateway to possible extinction. The image below demonstrates how spruce and fir forests were destroyed gradually since the forests were returned to their initial owner. 


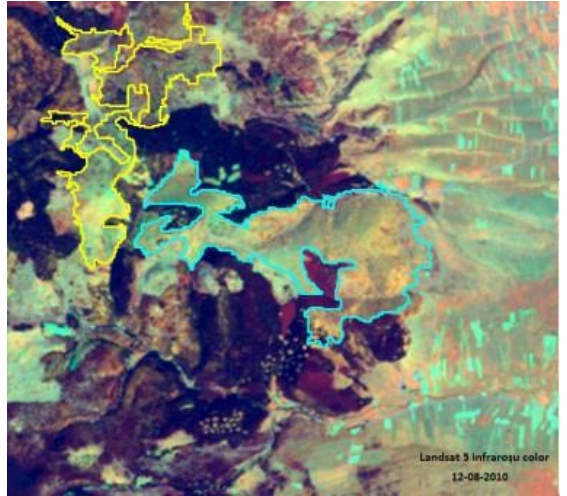

Figure 1. Courtesy NASA

Figure 1 for example: This image was taken by NASA, which is currently assisting the Institute of Research and Forestry Arrangement in Romania to monitor the forests, this picture, taken after the deforestation occurred, shows what is left of the forests in Romania.

During the communist regime, the in-school curricula taught good practices about how to behave in the natural world. There was a discipline taught called Knowledge about Nature, which was studied in $4^{\text {th }}$ grade and had a good practical side to it. We used to have special classes about planting trees and would go inside the natural reservation to clean the forests and waters and remove any unwanted traces of civilization. Nowadays this practice has stopped.

We study Ecology only as a concept, and nobody is bothering to take into account the practical side of this discipline. Teachers not only need to explain the concepts of nature and what Ecology means, but also demonstrate what preservation and conservation can do for improving people's quality of life. The children have learned from news and media that the forests in Romania are an endangered species, and they know that they can help, but nobody shows them the way. As we can see, everything lives in collaboration, and the disappearance of one unit triggers the destruction of the next one. Ecology has to go hand in hand with the education and preservation of nature.

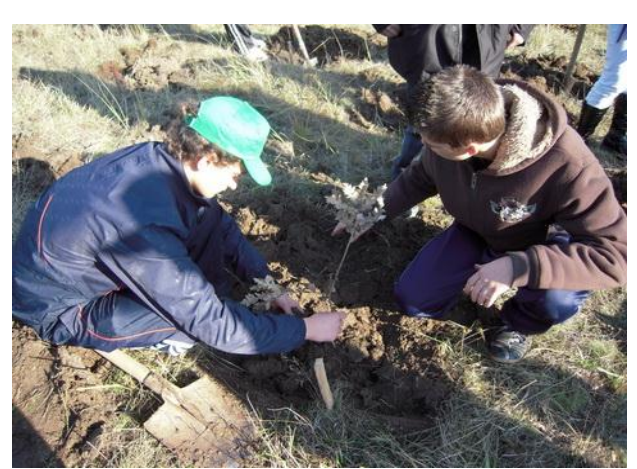

Figure 2. Prinde Radacini campaign. Courtesy http://www.rosilva.ro/
Thankfully in 2009, some civil societies started to take action and they created a movement called "Prinde Radacin?" or, in English, "Romania gets roots." It was a campaign organized by Realitatea TV and sustained by the OMV Petrom oil and gas company (http://www.petrom.com). In this campaign they started to plant trees in deforested areas, all on a voluntary basis. But this is not enough; it is only one drop in the sea. 
After Romania become part of European Union in 2007, politicians were forced to understand that forests and the environment are very sensitive issues in Europe, and they started to pay closer attention to what was happening at a national scale. From Europe came the idea of creating a model of earth education that would bring economic growth. In this paper I will focus on an educational program that brings ecological

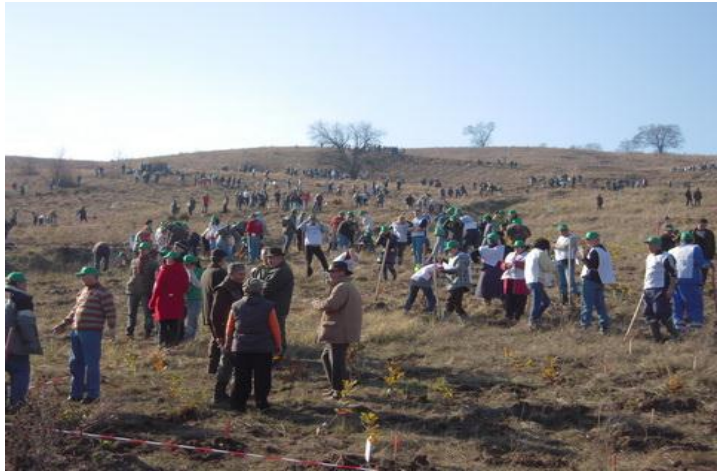

Figure 3. Prinde Radacini Campaign. Courtesy http://www.maimultverde.ro/ images/timis1.jpg education back into schools. This program is very important for creating awareness about the respect and proper use of natural resources and environment.

As David E. Gammon, Jennifer M. Platania, Susan Manring and David Muñoz envisioned:

Imagine an economic system structured so that decisions made by purely self-interested individuals result in environmentally beneficial outcomes. Imagine a system that rewards businesses seeking to achieve more than simple compliance with environmental regulation. Such a system is possible if prices accurately reflect the magnitude of environmental costs and benefits. In such a system, innovation that improves environmental performance would mean more than just good public relations; it would improve a company's bottom line. Everyone would win. (2011)

We have discovered a project, which will be the case for ecological education that tries to apply this idyllic image. The case being proposed is based on a European project, realized in partnership between two countries: Romania and Hungary. The motto of the project: "Two countries, one goal, and one common success!" is self-explanatory and is a collaborative cross-border economic and environmental program that started in 2010 and will end in December, 2013. The project was developed for a society called Societatea Carpatina Ardeleana from Satu Mare County, Romania. This research is part of the project under the title "Development of the Environmental Education Institutional Structure in the Cross-border Region", also part of the Cooperation Cross-border Program Grant Hungary -Romania 2007-2013. Financed by the European Regional Development Fund (ERDF), the focus of the report was on Educational Ecology. This subject is an umbrella of terms that covers very well the themes of PRME for this year. 
This project studied the quality of the air and environment. In this case, education about environment is not only a form of learning but also a tool that gives solutions for the environmental problems and key in taking care of the natural resources (and the forests are a very important part of the eco-system in this region). The project also talks about the Education about the Environment, which is the theoretical part of this program. This part ensures that the people understand the way natural systems function, and also the impact that human activities are having on natural systems. When applying the theoretical knowledge, people involved in this process will be able to make appropriate decisions in regards to the environment.

The second part of the project deals with the applicability of the Education into the Environment. This part will ensure the practical experience of learning about the environment by being directly in it This can be done through the following methods: collection of data on the terrain, or stimulation of the involvement and empathy for the environment by being actively there and observing the changes.

The concluding section, Education for Environment, presents the project's final product: education in and about the environment. Development of a sense of responsibility for the environment is a direct result, and motivates the individual to take an active part in protecting the environment. Moreover, that individual develops the wish and capacity to change his or her life to be in harmony with nature. Both the teachers and the students are getting involved in this concept, by learning to take care of the natural resources.

The ecological education, which is the main component of my case, presents the educational process in the Romanian schools through five fundamental elements that are based on individual concepts:

- The first educational process is Conscience. This concept helps the students to understand that there are choices that they can make as consumers, and that those choices can have multiple implications on the environment.

- Knowledge is the second concept, and through this theme students understand their relationship with living nature. The outcome of this concept is the fact that when the people involved in the process gain knowledge on how to interact with the environment, they can predict what problems are going to come on their way, and can foresee solutions in the solving of those problems.

- Attitude is the third concept and aids in the selection of personal alternatives in specific environmental situations.

ECJ Volume 3, No. 2, 2013: $\mathrm{e}^{3}=$ earth education economics 
- The fourth element is the Aptitude, and this attribute represents the abilities, talents and motivation that an individual has. This can be translated in practice as the "efficiency and competency in doing and solving with success of some specific tasks and activities." (Report, Ages 2010 - 2013, p.9).

- The last concept is Involvement, which encourage the students to apply the knowledge they got in school. In this situation, they are able to actively engage in the process of decision-making, and are also able to sustain their opinions. From the pedagogical point of view, this process can lead to a change in the individual's behaviour and also involves an increase of self-esteem.

Why is Ecological Education important? This discipline helps students to be aware of the environment and also makes them to be aware of their responsibilities for the environment in which he or she lives. The Ecological Education brings up the idea that the problems that are in the environment, a great majority of them, are caused by the people. When students learn about environmental education they are able to think about the proper solutions that can repair the damages that they have inherited. The students are taught how to perceive the true values, and learn that the protection of the environment has to become a "way of life" (Educatia Ecologica, 2010-2013, p. 4).

This project comes as an answer to the relationship that coexists between ecological education and the school curricula. Educational Ecology is an answer to the new worldwide priority of teaching future generations about the environment. As a part of this new wave, Romania has the following disciplines of study: Education from the point of view of ecology and Education for the conservation and protection of the nature.

Another question that this project poses is who is going to teach ecological education in kindergartens, elementary schools or high schools? Until now, the people involved in teaching this new discipline were those who were teaching Geography and Knowledge about Nature. At this moment, other teachers could be involved in this new discipline, teachers that are teaching mathematics, physics, mother tongue, religion, drawing, physical education etc. According to this research, not only teachers should get involved in the process of teaching of this discipline, but also members of not-for-profit foundations, ecological associations, and any other organizations that are promoting and supporting the ecological education. The teaching of this discipline from the side of nontraditional teachers involves learning a huge amount of information in regards with the environment, and also implies an understanding of the connections that coexist between the environment itself and the influence (positive or negative) of the human imprint. In the following diagram, the authors of the study have shown the relationship that is 
generated by Educational Ecology with Physics, Maternal Languages, Art, Biology, Mathematics, Religion, Chemistry, Other Subjects, Sociology and Geography (p. 7), as shown in the figure below.

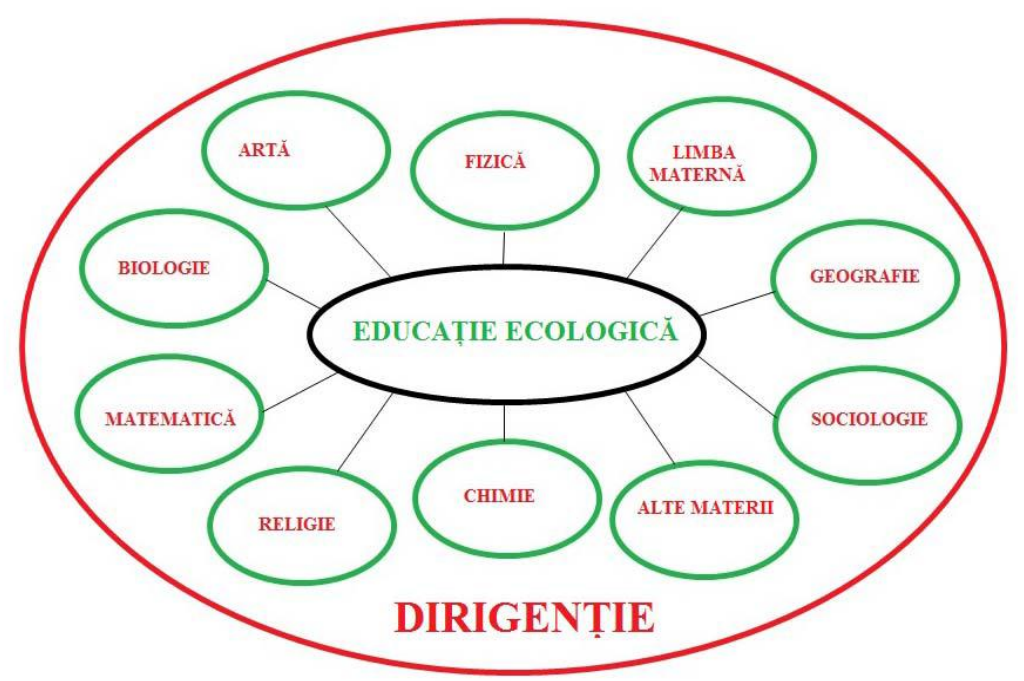

Figure 4. Educatia Ecologica

Why is it so important to get Educational Ecology back into the school curicula?

The major reason is the idea that the human population must take conscious action for the maintenance and improvement of the quality of nature. In Romania, the vast majority of the students don't have a formal educational ecology background: they leave empty paper bags, plastic bags, and cans in the schoolyard. This demonstrates that the children may not be exposed to the recycle inititive by neither their teachers in the school curicula nor by their parents at home. At this moment, Ecological Education is an elective course. As one of the ex-ministers of Environment stated "in schools, at this moment, we only have one hour dedicated to the study of the Environment, and is not enough" (Korodi Attila, 2010). According to Attila, Romanian schools need more hours in the curicula of the elementary and high schools dedicated to the study of Educational Environment. The requirements of the European curricula model called Green Package recommend that the environmental model be integrated into all school subjects such as mathematics, physics, chemistry, etc. The same minister reaffirmed that the environment problems should be studied not only in one textbook but also be part of the other 
textbooks, as a way of introducing the Green Package in as many subjects area as possible. (Combes, 2005).

At this moment, Romania has three projects and programs for ecological education awareness such as:

- We play and we recycle - this program of educational ecology was implemented for preschoolers in thirty-six daycares in Satu Mare county, between the $1^{\text {st }}$ of December 2008 and the $1^{\text {st }}$ of June 2009.

- Schools for a green future - this program was implemented by the Worldwide Fund for Nature between the $5^{\text {th }}$ of January and the $31^{\text {st }}$ of May 2010. This program resulted in a national contest called "Schools for Green Future." This program was adressed to all the elementaries and kindergardens from Romania as an informational manifesto for the preschoolers, kindergardens, students, teachers, parents, and the local authority about the actual problems of the environment. The contest was split into three sections based on the age level of the participants. There was PIPO for preschoolers and kindergardens, DOXI for elementary schools, and Terra Magazin for high schools.

- ECO SCHOOL is an international program that has as an objective the improvement of the quality of the environment. This program has specific activities that represent an ecological alternative to spend free time. The model offers the posibility to students to get involved in the solving of local environmental problems. The objective of the program is to increase the level of conscience of the student in regards to the environmental problems and with the elements of the sustainable development, that is realized in class by studying concrete actions at school and in the community.

\section{Methods used for teaching Educational Ecology in the Romanian Schools}

Educational Ecology can be realized through any type of school activity such as the observation of nature, experiments, trips, powerpoint presentations, games, ecological labyrinths, etc. The themes that can be followed are introduced by the function of the chosen subject or activity. For example, some potential themes could be: "To protect nature," "Pollution in different worlds," "Wintering with the plants and animals," "Our knowledge of forests", "Nature awakening to life," "Young tree, old tree," "Nature's lessons for us," and "Masks and ecological customs."

The specialists in the theory and educational practice define the above method as a "way of actions that helps the students, under the mentorship of the teachers to learn

ECJ Volume 3, No. 2, 2013: $\mathrm{e}^{3}=$ earth education economics 
about the environment, and to develop skills, aptitudes and attitudes towards this discipline of study" (Educatia Ecologica, 2011-2013, p. 11).

\section{Methods and techniques used in teaching of the Ecological Education}

1. For preschoolers there is oral communication (questions, problem solving); written communication (textbooks and text analysis), visual communication (the language of the word, image, and sound), and internal communication based on the internal language.

2. Systematic exploration of objective reality for kindergarden and elementary students. This can be realized directly (through systematic obsevation, study of the documents, and case study) or indirectly (demonstration, modelation, etc.).

3. Fundamental methods of practical action: externally, for real (exercising outside the classroom, practical works, and creative activities), imaginary, or simultative actions such as didactical games and simulation games (for elementary students).

4. Informational instruction for high school students: computer instructional sessions (interactive lessons offered by the program AEL-Advanced eLearning); simulations of some processee and natural phenomena in the school laboratories or in some of the lessons AEL; the usage of interactive maps and of satellite images, etc.

These methods have as a goal the knowledge and use of the notions about the environment to explain the same objective phenomena and the relation from the natural environment, development of the spirit of observation, investigation and research for the students, formation of a set of positive values for the environment, and motivation for participation in the maintenance of the quality of the environment.

The potential of the educational institution from Satu Mare County in the development and implementation of the Ecological Education projects

The program wants to ensure that there will be no more environmental situations like the one in the picture below. 


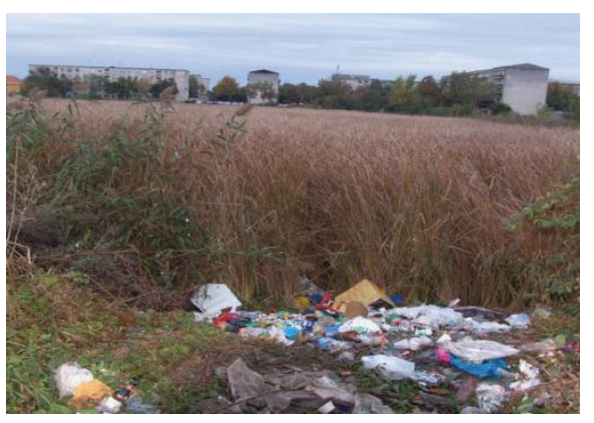

Figure 5. Courtesy of 10 Project Partner 8: Satu Mare [Romania]
This picture represents an improvised waste deposit. If the students will learn about the impact of waste on the environment, in the future they might sustain the construction of a modern and ecologically friendly waste deposit in the municipality of Satu Mare.

In Satu Mare, there are 505 educational institutions: 248 daycares and kindergardens, 230 elementary schools, three special schools for children with disabilities, twenty-six high schools, one trade school, one college, and five university extensions. With regards to literacy, Satu Mare is in $26^{\text {th }}$ place among the Romanian counties, and represents $67 \%$ of the students that are enrolled or part of high school and university environment. Moreover, $97.4 \%$ of Satu Mare's population is literate.

\section{Specific activities that took place in the institution that are recognized experts in} the practice of Ecological Education

The analysis about specific activities that have Ecological Education principles are based on interviews taken with public persons. In the process of discovery have been used secondary documents of the institution involved in this experiment. The data are from April 2010 and was collected from the following public institutions:

- City Hall of Satu Mare

- Municipality of Satu Mare

- The Agency for Protection of the Environment from Satu Mare

The following departments and offices participated in this case study:

From the City Hall of Satu Mare four persons participated in this analysis, two of them representing the Office for the Revitalization of the Green Space, and two from the Program of Economical Development and External Relations, which in our case is the European Integration.

At the interview held with agents from the Muncipality we had representatives from the Project Management and The Service for Implementation-which is also known as the Service of Implementation-Regional Waste Management. The interview held with 
the Agency for Environmental Protection from Satu Mare, was taken with the coordinator of the Department for Public Relations, Communication, Programs and Projects.

All data was collected to gain a better understanding of the Ecological Education implemented in this area. Another concern was how much budget was required for the implementations of those projects, and, of course, the future planning that involves the Ecological Education. Another reason was to evaluate what types of programs and projects can be develped in the future for this subject area. Some of the questions that were posed pertain to the below subjects:

- When was the first time when they heard about Ecological Education?

- When was the first legal conscience action of aknowledgement of the importance of the environmental education for youngsters and children (Students and after schoolers)?

- When did Biology became an important part of the teaching process prepared by the teachers from schools?

- When did City Hall from Micula, Satu Mare County became part of the protected area of the Ardelene Society Carpatina?

After the final interviews, the conclusion reached was that the local authorities know very well the actual problems of the enviroment. In 2000, the Agency for Enviromental Protection, which resides in Satu Mare, has started to include the preoccupation and integration for Ecological Education. The real action of integrating the preoccupation for the Ecological Education started in 2000 through the Agency for Environmental Protection from Satu Mare. The actions initiated by this Agency have been followed by the City Hall and the Municipality.

One example of unification of the efforts and partnership was between the local authorities and the Circle of Ecofriends formed of fifty children with ages between 14 and 18 years old, and was discussed in the weekly meetings organized every Wednesday. The children were able to discuss the everyday problems that happen in nature and what action they are going to take and make things right.

Another action taken into consideration by the local authorities was the implementation of some preparatory courses for the teachers in order to grasp new knowledge about ecological education. The teachers were also introduced to new types

ECJ Volume 3, No. 2, 2013: $\mathrm{e}^{3}=$ earth education economics 
of games and competitions with ecological themes that they can implement for children of all ages.

Another initiative promoted by this program was the correct selection of the residual waste by the local population. Another important progress that was regisitered after the implementation of the program was the constant effort from the side of the local authorities and the teachers to keep a clean environment. The table on the following page breaks down exactly the initiatives that each institution was responsible for creating.

\begin{tabular}{|c|c|c|}
\hline Number & Institution & The Project \\
\hline 1. & $\begin{array}{l}\text { City Hall of } \\
\text { Satu Mare }\end{array}$ & $\begin{array}{l}\text { - Creation of playgrounds for children with monetary help from the Fund from } \\
\text { the Environment. } \\
\text { - City Hall employees became involved in the collection of the residual waste } \\
\text { (garbage). }\end{array}$ \\
\hline 2. & $\begin{array}{l}\text { The } \\
\text { Agency for } \\
\text { the } \\
\text { Environme } \\
\text { ntal } \\
\text { Protection }\end{array}$ & $\begin{array}{l}\text { - "Life for Environment - life for the people" } \\
\text { - "Education for kids, for adults" } \\
\text { - "The International Eco-School" } \\
\text { - "The Circle Eco-Friends" } \\
\text { - "Let's give life to the parks" } \\
\text { - "Satu Mare - green city, Satu Mare - clean city" } \\
\text { - "Millions of people, millions of trees" } \\
\text { - "The Campaign Close, Turn Off, Recycle" } \\
\text { - "We play and we recycle" } \\
\text { - "The week of the European mobility: Mobility = Health" } \\
\text { - "Educational Complex of surveilliance of the quality of the air in the cross- } \\
\text { - "The Campaign of collecting used cooking oil" } \\
\text { - "AMBROSIA - Risk factor for environment and health" } \\
\text { - "Contest of collection of the PET recyclables in the honor of the International } \\
\text { - "Say of Cleaning" } \\
\text { for: Education for the Environment - Education for the Future" }\end{array}$ \\
\hline 3. & $\begin{array}{l}\text { The } \\
\text { Ministry of } \\
\text { Education } \\
\text { from Satu } \\
\text { Mare }\end{array}$ & $\begin{array}{l}\text { - "Schools for a green future - in the School Mihai Eminescu, Satu Mare } \\
\text { - Contest "Together in the European Union". In the Seven Edition the } \\
\text { participants were from Romania, Hungary and Slovenia. } \\
\text { - Together for the protection of the biodiversity" from the region Viile from } \\
\text { Satu Mare. This was field research. } \\
\text { - Cross-border program "Together in Europe" }\end{array}$ \\
\hline
\end{tabular}

From this table we can see that the Agency for the Environmental Protection has the greatest implication in the realization of the development and sponsorship of the

ECJ Volume 3, No. 2, 2013: $\mathrm{e}^{3}=$ earth education economics 
ecological educational initiative. Unfortunately, the Ecological Education is not part of a special budgeting system and relies mostly on donations and sponsorships.

Future planning involves new ideas such as the development of an Eco Center which will offer space for lectures and school activities (the school would ensure that the children stay for free). Another idea is the development of a partnership with the Society Carpatina Ardeleanu (EKE Szatmarnemeti) - the Satu Mare branch, and also the creation of a space that will offer the possibility for teachers to teach about ecology to kids coming for summer school. This centre will have a social component and will organize summer camps for children from poor families who don't have the resources to send their kids to another place for summer. In the end, all we can say about the ecological education is that it is a complex process of recognition of the values about the environment. We need to give the promotion that was intiated by the Satu Mare County a chance. In 2009 Satu Mare had shown a lot of initiative in the ecological education area and for its efforts has received international recognition. At the end of 2008, Satu Mare received the Green Flag from the World Wide Educational Foundation for the Environment.

Sometimes we just jump into the new without being prepared, even with good intentions, and we end up hurting the economic and ecological equilibrium. All of the three themes of the conference- $e^{3}=$ earth education economics - if treated as interrelated elements, will lead to a more careful exploration and in the end will bring to the nation more prosperity and understanding. One way to achieve this relation is by applying the principles of sustainable business practices and exploration.

* Author: Mia Isabela Deleanu is a graduate of the Library and Information Technology program at MacEwan University, as well as Records Management, a Human Resources Certificate (NAIT), and a Masters degree in Bulgarian Language and Literature. In 2008, Mia represented the Central University Library "Carol I" at the National Conference of Romanian Librarians with her paper "The Romanian Libraries in the Digital Word". She also published two papers, "The book a mysterious universe for the readers from XXI century" (2005) and "Kaleidoscope for Holiday" (2001) in Biblioteca-papers that commented on the presence of mind of today's readers and their reading habits.

She is also the author of three books: Caleidoscop (poetry, short fiction, and drama published in 2006), Wandering with Angels (short stories published in 2003), and The Merchant of Dreams (short stories, published in 2002), all of them under the name Isabela Barzoaga. Under the same name, she also published short stories and poetry in the Ferestre spre lumina "Windows into the light" (2002), Rascrucea dintre ganduri "Crossing

ECJ Volume 3, No. 2, 2013: $\mathrm{e}^{3}=$ earth education economics 
between the thoughts" (2002), and Strigatul din corn de luna "The scream from the half-moon" (2003) anthologies.

In 2011, Mia became involved in professional and student organizations including: Student Program Advisory Committee at Grant MacEwan University for the Library and Information Technology program, The Great Edmonton Library Association (GELA), Alberta Library Association (ALA), the Association of Records and Information Management (ARMA)_Edmonton Chapter (ARMA), and the Alberta Writers Guild. Currently, Mia is interested in getting more involved in understanding bow ecology is represented in school curricula.

\section{References}

Combes, B. (2005). The United Nations Decade of Educatation for Sustainable Development (2005 - 2014): Learning to Live Together Sustainably. Applied Environmental Education \& Communication, 4(3), 215-219.

David E Gammon, Jennifer M Platania, Susan Manring, and David Muñoz. (2011). Economics: the overlooked discipline in Earth Stewardship. Frontiers in Ecology and the Environment 9. 535-535. http:/ / dx.doi.org.ezproxy.macewan.ca/10.1890/15409295-9.10.535

Dawson, Chad P. (2009). Wilderness management: Stewardship and protection of resources and values. Boulder, CO.: WILD Foundation

Educatia Ecologica (2010-2013) [pdf] retrieved on 1 March from http://eke.ro/document/Raport\%20de\%20cercetare_EDUCATIE\%20ECOLOGI CA.pdf

Energy, transport and environment indicators - Eurostat -Europa (2012). March 1, 2013. Retrieved from: www.epp.eurostat.ec.europa.ca/cache/ITY.../KS-DK-11001-EN.PDF

Irwin, H. (2007). Restoring Nature's capital: An action agenda to sustain ecosystem services. Washington, DC: World Resources Institute.

Romania Libera (12 October, 2012) Imagini Nasa confirma dezastrul din padurile romanesti: o suprafata uraisa de molid a disparut din Harghita in numai trei ani. March 2, 2013. Retrieved from: http://www.romanialibera.ro/exclusivrl/investigatii/imagini-nasa-confirma-dezastrul-din padurile-romanesti-o-suprafatauriasa-de-molid-a-disparut-din-harghita-in-numai-trei-ani-280819-main_pic4.html 
Romania prinde radacini/ Mai mult verde (nov. 2009). Article retrieved on 1 March 2013 from http://www.maimultverde.ro/project/romania-prinde-radacini

Satu Mare Urbact [pdf] (2010). Retrieved 3 March 2013 from http://urbact.eu/fileadmin/Projects/Reg_Gov/partners_media/CP_Satu_Mare.pd $\mathrm{f}$

Shin, D. S. (2000). Environmental education course development for preservice secondary school science teachers in the Republic of Korea. Journal of Environmental Education, 31(4). 11-18. (retrieet April 12, 2013)

Wilderer P. A. Schroeder E.D \& Kopp, H. (2005). Global sustainability: the impact of local cultures: a new perspective for science and engineering, economics and politics. Wiley: VCH. 


\section{Appendix I: Collected Data by Eurostat/European Environment Agency}

The following screenshots offer collected data by Eurostat and the European Environment Agency and are from the chapter: Forestry and Biodiversity (pp. 182-186), Energy, transport and environment indicators - 2012.

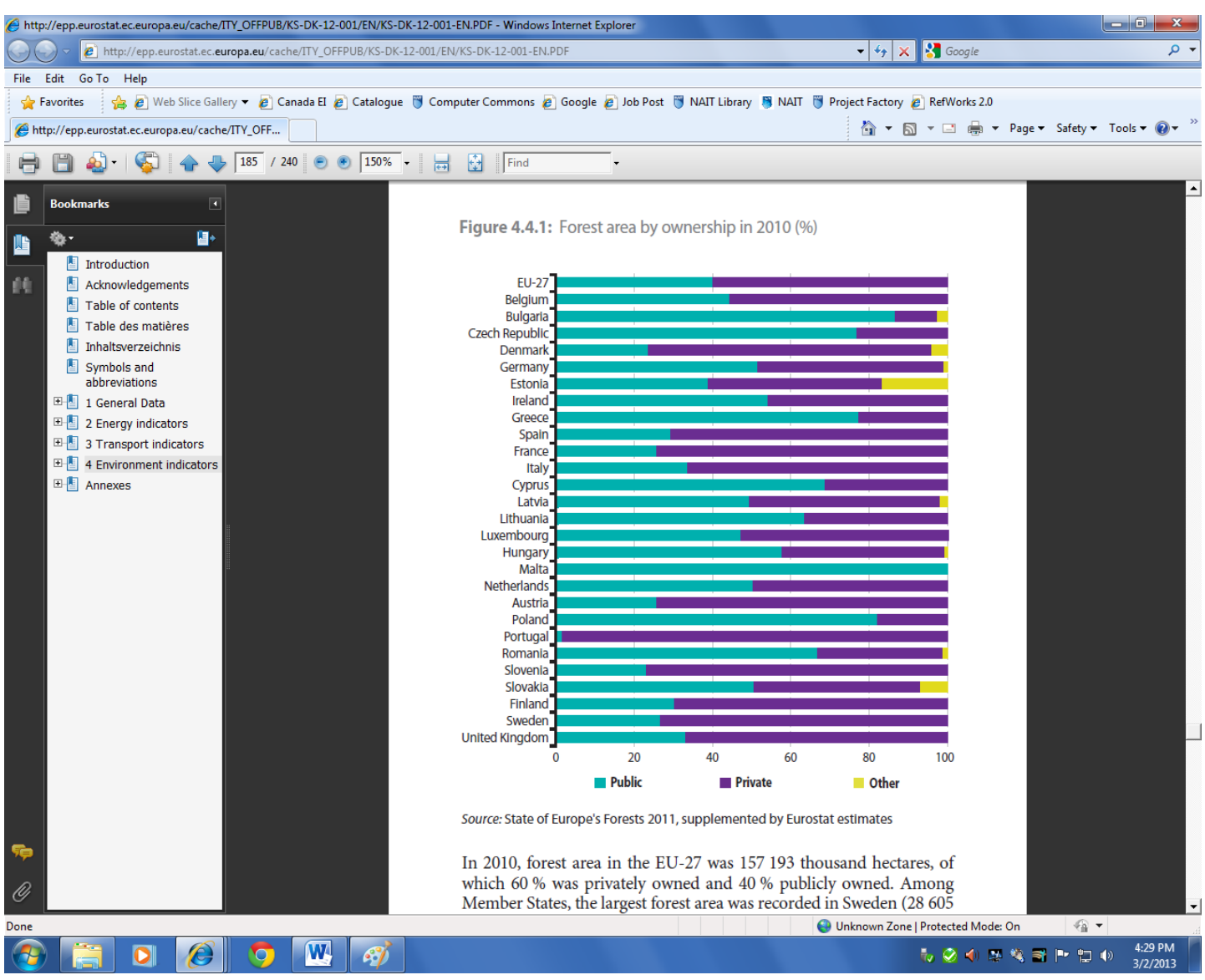

ECJ Volume 3, No. 2, 2013: $\mathrm{e}^{3}=$ earth education economics 


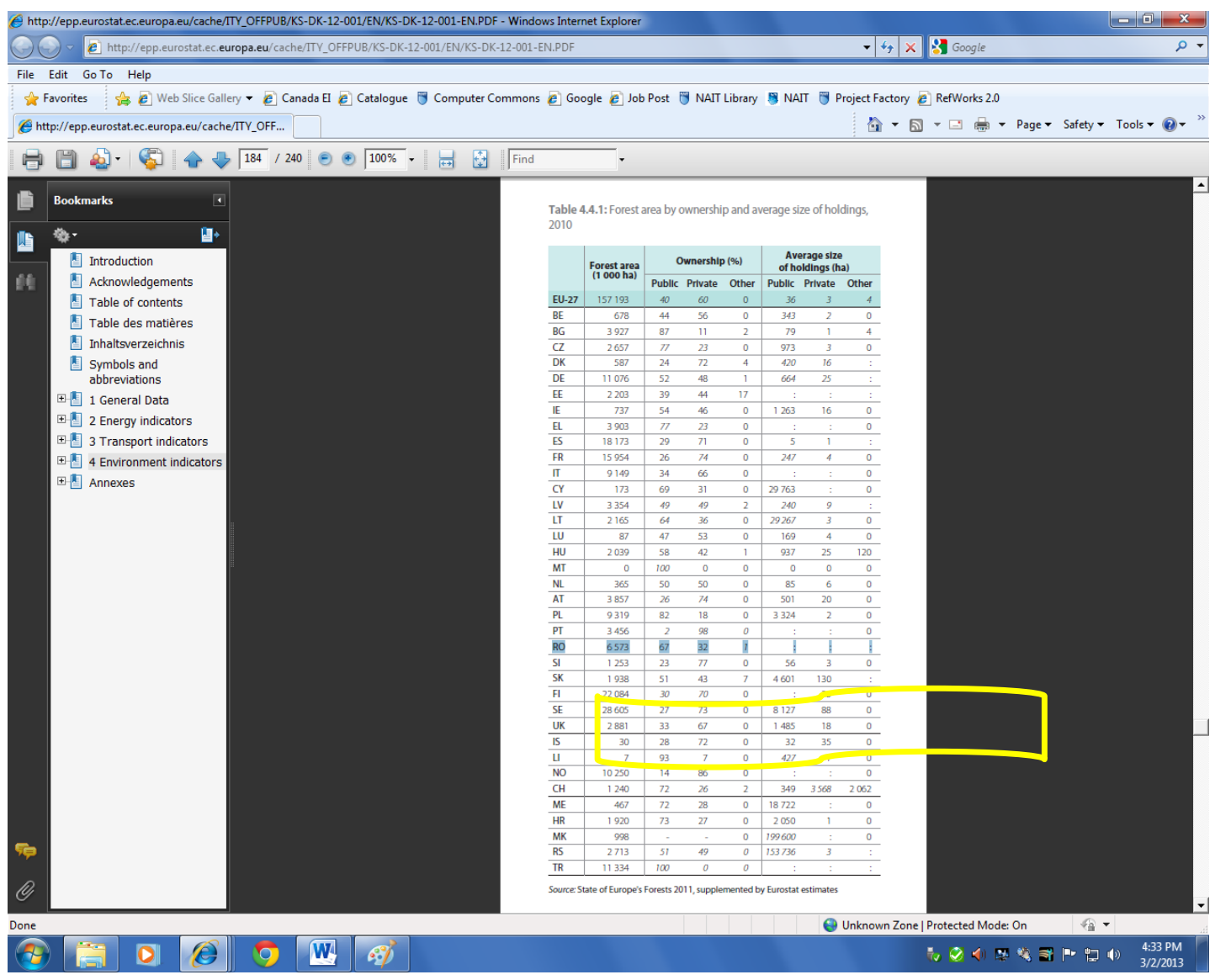

ECJ Volume 3, No. 2, 2013: $\mathrm{e}^{3}=$ earth education economics 


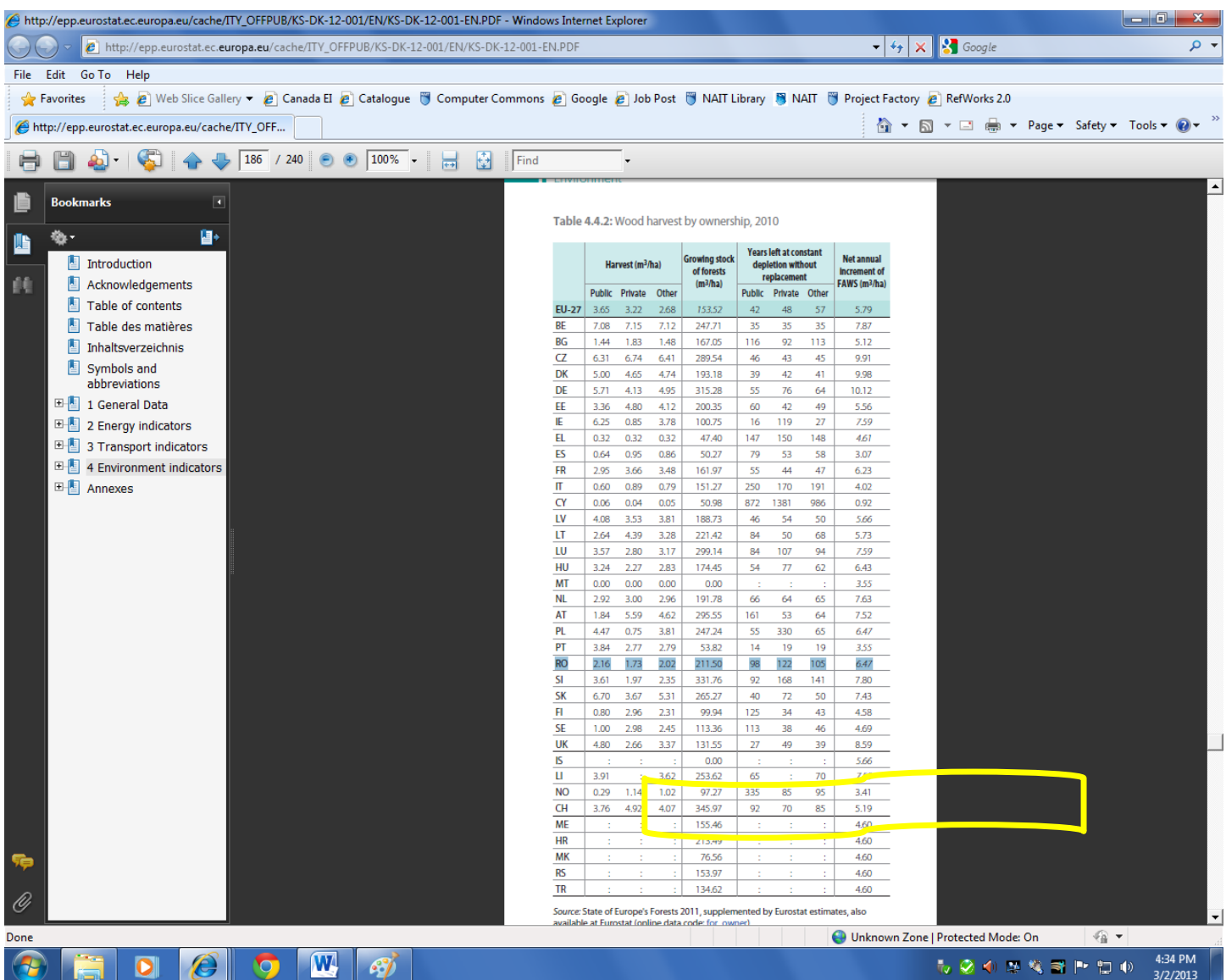

ECJ Volume 3, No. 2, 2013: $\mathrm{e}^{3}=$ earth education economics 


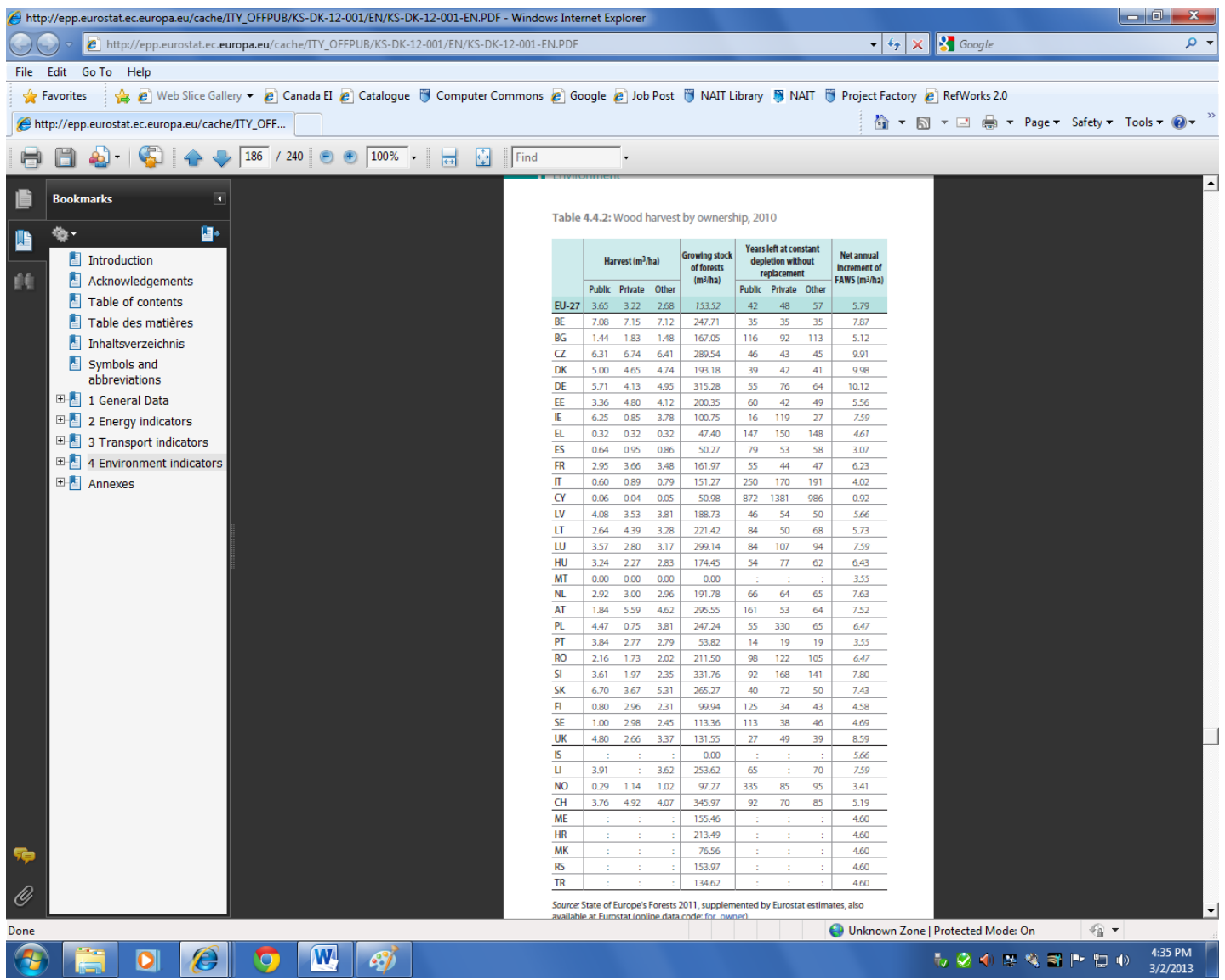

ECJ Volume 3, No. 2, 2013: $\mathrm{e}^{3}=$ earth education economics 


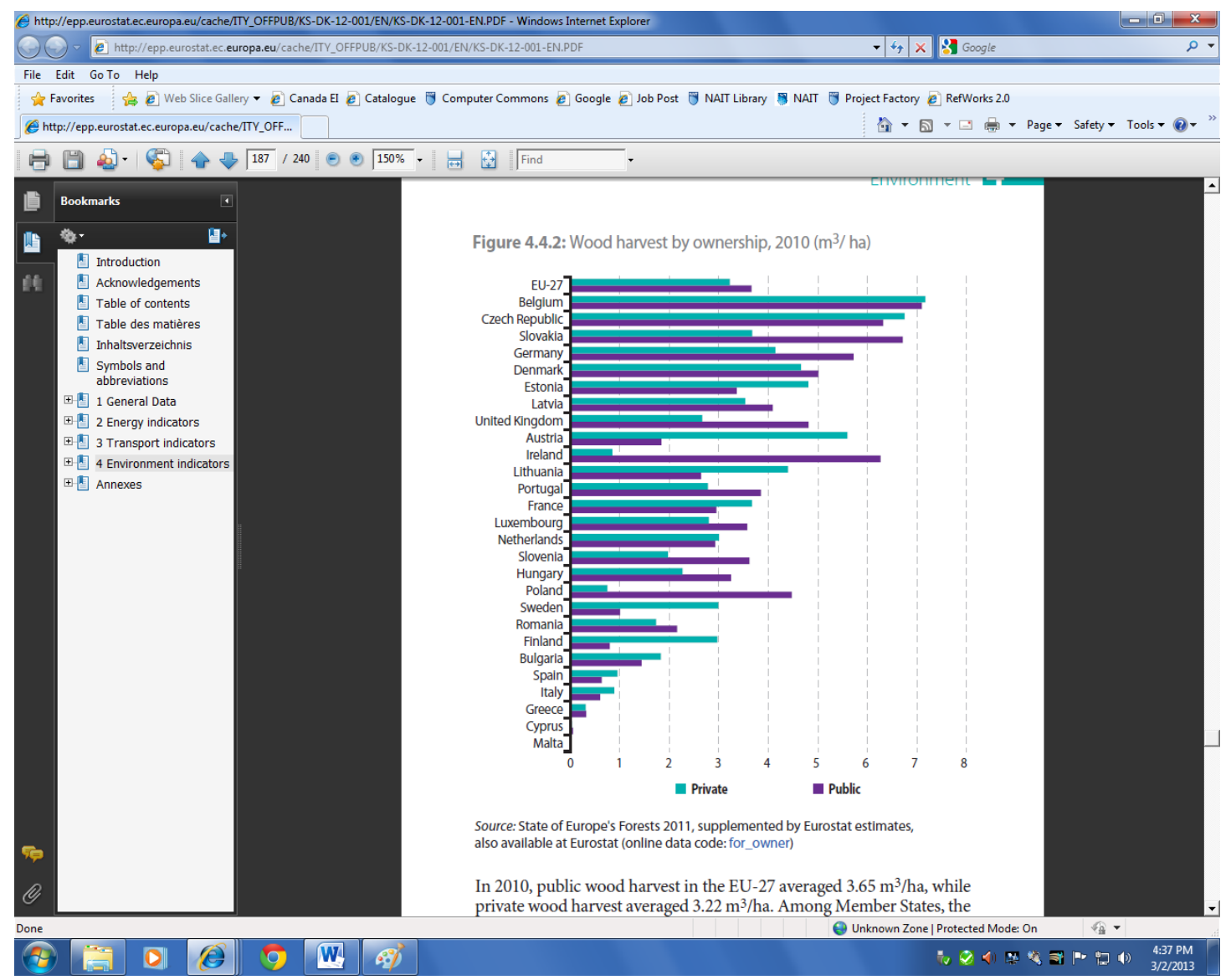

In 2010, public wood harvest in the EU-27 averaged $3.65 \mathrm{~m} 3 /$ ha, while private wood harvest averaged $3.22 \mathrm{~m} 3 /$ ha. Among member states, the highest values were recorded in Belgium (7.08 for public and 7.15 for private). High values for public harvest were also recorded in Slovakia (6.70) and the Czech Republic (6.31), while private harvests were high in the Czech Republic (6.74) and Austria (5.59).

The density of growing stock of forests for the EU-27 averaged $153.52 \mathrm{~m} 3 /$ ha in 2010. The Member States with the highest growing stock densities occurred in Slovenia (331.76) and Germany (315.28), while the lowest values were observed in Malta (0), Greece (47.40), Spain (50.27), and Cyprus (50.98).

In 2010, the average net annual increment in the EU's forests that were available for wood supply was $5.79 \mathrm{~m} 3 / \mathrm{ha}$. Among member states, the net annual increment ranged from $0.92 \mathrm{~m} 3 /$ ha in Cyprus to $10.12 \mathrm{~m} 3 /$ ha in Germany. 
The European Union's policy to fight illegal logging and associated trade was defined in 2003 with the Forest Law Enforcement, Governance and Trade (FLEGT) Action Plan. The key regions and countries targeted in the FLEGT Action Plan, which together host nearly $60 \%$ of the world's forests and supply a large proportion of internationally traded timber, are tropical Africa, Russia, tropical South America, and southeastern Asia. The FLEGT Action Plan, endorsed by the EU Council of Ministers in November 2003, covers both supply-side and demand-side measures to address illegal logging. A key element of the FLEGT Action Plan is a voluntary scheme to ensure that only legally harvested timber is imported to the EU from countries participating in the scheme. The EU's legal framework (Eurostat Pocketbooks, p.185) is a regulation adopted in December 2005 and a 2008 Implementing Regulation. They allow for the control of timber imported to the EU from countries that have entered into bilateral FLEGT Voluntary Partnership Agreements (VPA) with the EU. The European Commission has been given a mandate from the Council of Ministers of the EU to conduct negotiations in view of concluding such FLEGT VPAs. The first VPA to be concluded was with Ghana. 